\title{
Analysis of Medical Worker Satisfaction Level Towards the Implementation of Digitalized E-Health Applications of Health Services at Member of Indonesian Clinic Association in Kediri 2021
}

\author{
Ishak Sulistianto Rahardjo ${ }^{\mathbf{1}}$, \\ Ratna Wardani ${ }^{2}$ \\ ${ }^{1}$ Pharmacist in Mahkota Pharmacy \\ Clinic Instalation, \\ ASKLIN Kediri Branch Secretary \\ ${ }^{2}$ Public Health Posgraduate Study \\ Program, Institute of Health Sciences \\ Strada Indonesia \\ Email: \\ ishak.s.rahardjo@gmail.com
}

Received : October $4^{\text {nd }} 2021$

Accepted : October $15^{\text {rd }} 2021$

Published : November $27^{\text {th }} 2021$

\begin{abstract}
Health services that are easy to access, fast, safe, confidential, integrated, effective and efficient are demands on the quality of public services, especially for health sector in the Disruption Era. The purpose of this research was to determine the extent of the SimKes (e-health) application implementation and to explore supportive and impeding factors of health service digitalization at the member clinics of ASKLIN Kediri Branch so that it affects the medical workers' satisfaction as an application user.

The method used in this research is qualitative approach which defined as a research procedure that produces descriptive data. Collecting data using Purposive Sampling by in-depth interview techniques with semi-structured questions to 14 informants and 2 Triangulators Data Sources, namely the founder and creator of SimKes Khanza and the head of the BPJS Kesehatan's Participant Benefits Guarantor Kediri Branch.

From the research's results, it is known that the SimKes (ehealth) application has been used in all health service line in almost all ASKLIN member Clinics in Kediri Branch and the satisfaction level of medical workers using the SimKes (e-health) application ranges from $75-80 \%$. The constraints in implementing SimKes application have been successfully mapped, including application users' age, data networks and application customization, financing to other profession technical matters, which can increase the satisfaction of medical workers who use e-health applications if they get the right treatment.

The implementation of the Health Management Information System (SimKes) application in digital health services (telemedicine/ehealth) is expected to maximize health services at Health Service Facilities, especially at the member Clinics of the Indonesian Clinic Association, Kediri Branch. Digitalized health service implementations are expected to provide reliable and integrated data and information so that they can become a tool for effective and efficient management of health development.
\end{abstract}

Keywords: Health service application, SimKes, e-health

Copyright (C) 2021 IIK STRADA Indonesia All right reserved.

This is an open-acces article distributed under the terms of the Creative Commons Attribution-ShareAlike 4.0 International License. 


\section{INTRODUCTION}

Health services that are easy to access, fast, safe, confidential, integrated, effective and efficient are demands on the quality of public services, especially for health sector in the Disruption Era (Deloitte, 2018). The development of conventional health services into the digitalized health services is expected to maximize health service in Health Service Facilities and can improve the performance and quality of medical workers, especially through the implementation of a digitalized Health Management Information System application (telemedicine/e-health) (Brucher et al., 2018). The purpose of this research was to determine the extent of the SimKes (e-health) application implementation and to explore supportive and impeding factors of health service digitalization at the member clinics of ASKLIN Kediri Branch so that it affects the medical workers' satisfaction as an application users.

\section{MATERIALS AND METHODS}

The method used in this research is qualitative approach which defined as a research procedure that produces descriptive data (Raco, 2018). This research protocol has received ethical approval from the Health Research Ethics Committee IIK STRADA Indonesia no. 2268/KEPK/II/2021 dated February 9, 2021. Collecting data using Purposive Sampling by in-depth interview techniques with semi-structured questions to 14 informants representing Clinics/Pharmaceutical Installations, members of the Indonesian Clinic Association, Kediri Branch, which consist of physicians, dentists and pharmacists, because health services at the Clinic generally rely on the services provided by these personnels. The triangulation used is using Data Sources (Lexy J. Moleong, 2002), namely the Founder and Creator of SimKes Khanza and the head of the BPJS Kesehatan's Participant Benefits Guarantor Kediri Branch.. This research was conducted in MayJuly 2021. The data from the interviews were taken through face to face meetings and online meetings via zoom application media and whatsapp video calls considering the restrictions on activities related to the Covid-19 pandemic.

\section{Table of Informants Characteristics}

\begin{tabular}{|c|c|c|c|c|c|}
\hline No. & Age & Gender & Education & Functional & Duration of Practice \\
\hline 1 & 35 & M & S2 & Physician & 10 years \\
\hline 2 & 52 & M & S1 & Physician & 24 years \\
\hline 3 & 29 & F & S1 & Physician & 5 years \\
\hline 4 & 44 & F & S1 & Pharmacist & 20 years \\
\hline 5 & 37 & F & S2 & Pharmacist & 8 years \\
\hline 6 & 32 & M & S1 & Pharmacist & 5 years \\
\hline 7 & 48 & F & S2 & Pharmacist & 23 years \\
\hline 8 & 36 & F & S1 & Pharmacist & 12 years \\
\hline 9 & 29 & F & S1 & Physician & 4 years \\
\hline 10 & 40 & F & S1 & Pharmacist & 15 years \\
\hline 11 & 39 & M & S1 & Pharmacist & 14 years \\
\hline 12 & 35 & F & S1 & Pharmacist & 8 years \\
\hline 13 & 43 & F & S1 & Physician & 16 years \\
\hline 14 & 39 & F & S1 & Dentist & 4 years \\
\hline
\end{tabular}

\section{RESULTS}

From the research results, it is known that the SimKes (e-health) application has been used in 13 of the 14 Clinics/ Pharmacy Clinic Installations that are members of the Indonesian Clinic Association Kediri Branch. The applications used include P-Care BPJS Kesehatan, Alodokter, Halodoc (Wikipedia, 2020), GoApotek and SIPNAP (Orami Parenting, 2020) . In some clinics, more than 1 SimKes (e-health) application has been implemented simultaneously (total) while some Clinics have implemented the SimKes (e-health) application partially in the services provided.

The implementation of SimKes (e-health) application has covered the entire flow of health services start from Registration, Services, Radiology, Laboratories, Pharmacy Services (sales and delivery) 
to ambulances. In some cases, the SimKes (e-health) application has not been well integrated with all service flows but this does not interfere with the performance and quality of health services. This is inseparable from adherence to Standard Operating Procedures (SOP) for each service provided. Constraints/obstacles in implementing SimKes (e-health) application have been mapped, including the age factor of application user, the data network factor, the application customization factor, the financing factor to other profession technical matters. These constrain factors can improve the performance and quality and satisfaction of medical workers using the SimKes (e-health) application if it get the proper treatment.

The interviews result with informants using the SimKes (e-health) application showing that the satisfaction level of medical workers as the application users ranges from $75-80 \%$ and a scale value of 3 out of 5 with several notes including the e-health application is not user-friendly enough and still not well customized according to Clinic condition and frequent technical obstacles such as system errors. Manual work is still being carried out in several parts to create value and control, including KIE (Komunikasi Informasi dan Edukasi) and online diagnostics. However, in general, it is stated that the e-health application is very helpful, especially in pharmacy services (sales and delivery), reporting to related offices and can increase effectiveness and efficiency in services and reduce waste.

\section{DISCUSSION}

Health Management Information System (SimKes) application in digital health services (telemedicine/e-health) has produced a standard to be able to maximize health services in Health Service Facilities, especially in the member Clinics of the Indonesian Clinic Association, Kediri Branch (Savafi et al., 2019). In accordance with the Health Minister of the Republic of Indonesia Decree number 192/Menkes/SK/VI/2012 concerning the Action Plan Roadmap for Strengthening the Indonesian Health Information System (Kemenkes RI, 2012) it is a reference in planning, mobilizing, implementing and evaluating efforts to develop and strengthen Health Information Systems. The development and strengthening of the Health Information System is carried out by taking into account the principles of Information and Communication Technology (ICT) utilization, Data Security and Confidentiality, Standardization, Integration, Ease of Access, Representation and Ethics, Integrity and Quality.

The utilization and implementation of SimKes (e-health) application is expected to be able to facilitate services access in each service section (flow), starting from the Registration section, Examination Services by medical personnel, Supporting Services such as Laboratory and Radiology to Pharmacy Services and Aid Services such as shuttle services for prescription/medicine and ambulance. Research conducted by (Meyliano, 2015) entitled Public Service Innovation in the Disruption Era (Study on the Sustainability of E-Health Innovation in Surabaya City) states that public service innovation in the disruption era where public services are always associated with an activity to provide assistance and convenience to the public society in order to achieve certain goals. Health service innovation through e-health is an innovation developed to make it easier for the public to shorten the queue at Care Centre or Hospitals. Surabaya City's e-health application is a superior innovation that included in the Top 25 public service innovations at the national level in 2015.

In its implementation, the SimKes (e-health) application cannot be separated from the obstacles that greatly affect the service quality and application users' satisfaction (Dutta et al., 2020).

First, the age factor of application users, the application users' ability has a big role in maximizing application functions. In the first use of the application there are difficulties and even resistance to the use of the new application. The resistance increases directly with the age of the user. What helps is that the work is repetitive (repeated) so over time, application users become accustomed and it seems easy (Taylor, 2015).

Second, the data network factor greatly affects the quality of service using the SimKes (e-health) application. If not handled properly, this can actually slow down services and contradict the implementation nature of SimKes (e-health) application in providing fast and qualified services (Khalifa, 2013).

Third, the appropriate application customization factor is also able to support services at Health Service Facilities so customized e-health services are highly recommended in providing maximum support for services at the Clinic.

Fourth, the financing factor has a fairly important role to get a suitable and integrated application. The informants agreed that the SimKes (e-health) development requires a large amount of money 
because SimKes demands to be implemented in all Health Service Facilities' services flows (Taylor, 2015).

Fifth, profession technical matters factors. In healthcare industry there are things that cannot be fully managed and automated. Although this is still pros and cons in some scientific views. The examination's automation by medical personnel and KIE drugs provision, basically in many cases cannot be fully submitted without manual work intervention (Winarto et al., 2020).

User satisfaction for using the SimKes (e-health) application at the Clinic is an impression of the user's acceptance or rejection of the SimKes (e-health) application performance. In the end, the Health Information and Management System must provide results (outputs) that can be felt by all service users using the application. Entering the disruption era, standardized services, speed of service, service integration, security and data confidentiality are something that is absolutely required, especially in its implementation to public services access, such as health services in clinics. The path analysis research conducted by (Normasari et al., 2013) entitled The Effect of Service Quality on Customer Satisfaction, Company Image and Customer Loyalty can be seen that: (1) service quality variables have a significant influence on customer satisfaction variables; (2) the service quality variable has a significant influence on the corporate image variable; (3) Service Quality variable has no significant effect on Customer Loyalty variable; (4) Customer Satisfaction variable has a significant influence on the Corporate Image variable; (5) Customer Satisfaction variable has a significant effect on Customer Loyalty variable; (6) the corporate image variable has a significant influence on the customer loyalty variable.

SimKes application user satisfaction (e-health) ranges from $75-80 \%$ and a scale value of 3 out of 5 with a few notes, namely that the e-health application is not user-friendly and is not customized according to clinics conditions and the occurrence of technical obstacles such as system errors. Manual work is still needed to create value and control. However, the informants agreed that the ehealth application is very helpful in providing services at the clinic, especially in pharmacy services (sales and delivery), reporting to related agencies and reducing waste.

\section{CONCLUSION}

The implementation of the Health Management Information System (SimKes) application in digital health services (telemedicine/e-health) is expected to maximize health services at Health Service Facilities, especially at the member Clinics of the Indonesian Clinic Association, Kediri Branch. Researcher sees that the use of the SimKes (e-health) application is very helpful for officers or service providers so that the queue line going faster, medical recording is more complete but carried out in a simple way as well as requests for other services such as laboratories and radiology, emergency referrals to prescribing services (drugs order and delivery) can be done easily and quickly. Digitalized health service applications can provide reliable and integrated data and information so that they can become a tool for effective and efficient management of health development (Brucher et al., 2018).

Therefore, researcher encourage all Health Service Facilities to immediately apply Health Management System (e-health application) as an appropriate, effective and efficient medium in providing standardized, integrated, accessible, fast health services and guarantees data security and confidentiality. Asosiasi Klinik Indonesia (ASKLIN) as health facility association can strengthen the position and legal legitimacy in creating a health services standard in clinics based on the application of the Health Management Information System as a standard for health services in health facilities (Eddi Junaidi, Dr., SpOG, S.H., 2012).

The Health Ministry as a regulator can periodically review policies related to Health Management System data use (e-health applications) so that technical constraints and obstacles such as electronic prescribing (e-prescribing) validity get a strong legal basis as a valid and recognized document as well as other new innovations that continue to grow can be accommodated so they do not conflict with other laws and regulations.

\section{ACKNOWLEDGMENTS}

The author is thankful for respondents for their valuable information and their awareness to participate in this research and in particular for Prof. Dr. H. Sandu Siyoto, S.Sos.,S.KM.,M.Kes. (late) who has given a lot of support and invaluable input so that this research can be completed. 


\section{CONFLICTS OF INTEREST}

The author declares that they have no conflict of interest

Website : http://jurnal.strada.ac.id/jqph Email : jqph@strada.ac.id

\section{REFERENCES}

Brucher, L., Pontet, K., Duprel, C., Mosel, K., \& Moujahid, S. (2018). A journey towards smart health: the impact of digitalization on patient experience. Deloitte, February, 24.

Deloitte. (2018). 21 st Century Health Care Challenges : A Connected Health Approach. 1-114.

Dutta, B., Hwang, H. G., \& Wane, D. (2020). The adoption of electronic medical record by physicians: A PRISMA-compliant systematic review. Medicine (United States), 99(8). https://doi.org/10.1097/MD.0000000000019290

Eddi Junaidi, Dr., SpOG, S.H., M. K. (2012). ASOSIASI KLINIK INDONESIA (Ed. Revisi). Asosiasi Klinik Indonesia. https://asklin.org/

Kemenkes RI. (2012). Keputusan Menteri Kesehatan Republik Indonesia Nomor 192/menkes/sk/vi/2012 tentang. 2008, 4-72.

Khalifa, M. (2013). Barriers to health information systems and electronic medical records implementation a field study of Saudi Arabian hospitals. Procedia Computer Science, 21, 335342. https://doi.org/10.1016/j.procs.2013.09.044

Lexy J. Moleong. (2002). Metodologi Penelitian Kualitatif. PT. Remaja Rosda Karya.

Meyliano, R. D. P. (2015). Inovasi Pelayanan Publik di Era Disrupsi (Studi tentang Keberlanjutan Inovasi E-Health di Kota Surabaya). Journal of Chemical Information and Modeling, 53(9), $1689-1699$.

Normasari, S., Kumadji, S., \& Kusumawati, A. (2013). Pengaruh Kualitas Pelayanan Terhadap Kepuasan Pelanggan, Citra Perusahaan Dan Loyalitas Pelanggan. Jurnal Administrasi Bisnis (JAB).

Orami Parenting. (2020). Telemedicine Jadi Alternatif Saat Pandemi, Ini Kelebihan dan Kekurangannya. https://www.enervon.co.id/article/1706/telemedicine-jadi-alternatif-saatpandemi-ini-kelebihan-dan-

kekurangannya?utm_source=covid19_web\&utm_medium=homepage\#: :text=Salah satu kelemahan utama dalam,ini perlu memerlukan biaya tambahan.

Raco, J. (2018). Metode penelitian kualitatif: jenis, karakteristik dan keunggulannya. https://doi.org/10.31219/osf.io/mfzuj

Savafi, K., Webb, K., \& Kalis, B. (2019). Accenture 2019 Digital Health Consumer Survey. In Accenture 2019 Digital Health Consumer Survey US Results (pp. 1-13). https://www.accenture.com/_acnmedia/PDF-94/Accenture-2019-Digital-Health-ConsumerSurvey.pdf\#zoom $=50$

Taylor, K. (2015). Connected health - How digital technology is transforming health and social care. Deloitte, 40.

Wikipedia. (2020). Halodoc. https://id.wikipedia.org/wiki/Halodoc

Winarto, W., Wijayanti, M. T., \& Ummahati, L. (2020). Inovasi Pelayanan Kesehatan Berbasis Elektronik Melalui Sistem Informasi Kesehatan Nasional Online Dan Primary Care BPJS Di Dinas Kesehatan Kota Malang. Tantangan Penyelenggaraan Pemerintahan Di Era Revolusi Industri 4.0, 493-511. 